Article

\title{
Long-Term Effect of Manure and Mineral Fertilizer Application Rate on Maize Yield and Accumulated Nutrients Use Efficiencies in North China Plain
}

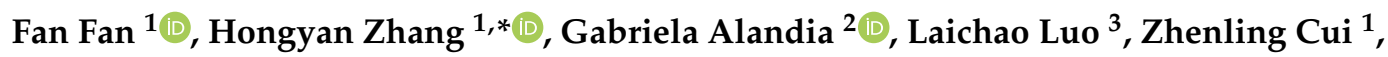 \\ Xinsheng Niu ${ }^{1}$, Ruili Liu ${ }^{1}$, Xiaoning Zhang ${ }^{1}$, Yu Zhang ${ }^{1}$ and Fusuo Zhang ${ }^{1}$ \\ 1 College of Resources and Environmental Sciences, China Agricultural University, Beijing 100193, China; \\ fanfan_happy@outlook.com (F.F.); cuizl@cau.edu.cn (Z.C.); xinshengniu@163.com (X.N.); \\ liuruili5212006@163.com (R.L.); lunalovetears@163.com (X.Z.); \\ zhangyu4611@163.com (Y.Z.); zhangfs@cau.edu.cn (F.Z.) \\ 2 Department of Plant and Environmental Sciences, Faculty of Science, University of Copenhagen, \\ 2630 Taastrup, Denmark; gar@plen.ku.dk \\ 3 Anhui Province Key Lab of Farmland Ecological Conservation and Pollution Prevention, School of \\ Resources and Environment, Anhui Agricultural University, Hefei 230036, China; lcluo@ahau.edu.cn \\ * Correspondence: zhanghy@cau.edu.cn; Tel.:+86-10-62732499
}

Received: 9 June 2020; Accepted: 31 August 2020; Published: 4 September 2020

\begin{abstract}
Overuse of mineral fertilizer has become common at the North China Plain. Simultaneously, more organic manure resources are available for smallholder farmers. In order to increase the use of organic manure and reduce mineral fertilizer applications, a 10-year fertilization experiment with maize took place between 2008 and 2017. We assessed the long-term effects of cattle manure (CM) application and a complete nutrient substitution with mineral fertilizer (MF) at four application levels $\left(3,6,9\right.$ and $\left.12 \mathrm{tha}^{-1} \mathrm{CM}\right)$ on yield, macronutrients $(\mathrm{N}, \mathrm{P}$ and $\mathrm{K})$ use efficiencies and soil conditions. Results showed that maize yields from $\mathrm{CM}$ and MF treatments differed across time and were significantly different in the first year of the experiment to no significant differences with increasing experimental time. In addition, increased MF levels did not result in increased maize yields; this response was different with $\mathrm{CM}$ applications. The highest 10-year maize average yield was $7.7 \mathrm{t} \mathrm{ha}^{-1}$ obtained with $9 \mathrm{t} \mathrm{ha}^{-1}$ of $\mathrm{CM}$. Our results also showed that at the lowest application level $\left(3 \mathrm{tha}^{-1} \mathrm{CM}\right)$, the partial factor productivity (PFP) and the agronomic efficiency (AE) of all macronutrients were significantly higher with MF than with CM applications. Nevertheless, these differences narrowed with increased fertilizer input levels. The MF and CM recovery efficiency (RE) of N, P and K performed differently. Generally, MF exhibited significantly higher N-RE than $\mathrm{CM}$ treatments. CM treatments had significantly higher P-RE, but no K-RE differences were found between CM and MF. Soil available N, P and K significantly increased when fertilizer levels raised. MF treatments exhibited similar levels of soil available $\mathrm{N}$, but lower soil available $\mathrm{P}$ and $\mathrm{K}$ compared with $\mathrm{CM}$ treatments.
\end{abstract}

Keywords: cattle manure; soil nutrient; fertilization rates

\section{Introduction}

China's total grain production has doubled between 1980 and 2015 [1]. However, fertilizer annual consumption increased five-fold [1]. China's nitrogen (N) consumption reached 60.2 million tons nationally in 2015 [1], which account for 40\% of global consumption [2]. China is the world's largest chemical fertilizers consumer. However, overuse of mineral fertilizer, especially $\mathrm{N}$, has been regarded as the major contributor of agricultural pollution and environmental damages. Nutrients leach to 
ground water leading to eutrophication and reactive $\mathrm{N}$ (e.g., $\mathrm{NH}_{3}, \mathrm{~N}_{2} \mathrm{O}$ ) is emitted to the atmosphere. The current challenge for Chinese agriculture development is to obtain high grain yields to ensure food security and simultaneously mitigate pollution to protect human health and the environment.

Maize is an important crop for China's food security; it is used as food, animal feed, forage and bio-fuel. The North China Plain (NCP) is one of the most important cereal production regions of China. Maize production from the NCP accounts for 35.3\% of nation's total maize production [1]. Nevertheless, in China, the increasing rate of maize yields has noticeably slowed down during the last decades, despite increased application of $\mathrm{N}$ and $\mathrm{P}$ fertilizers [1]. Increasing mineral fertilizer to obtain higher yield is no longer a viable option in China. At the NCP region, N application rates for maize production adopted by farmers were much higher than the crop requirements. Therefore, reducing the mineral fertilizer used and replacing it by organic fertilizer has been considered as an efficient farming management practice to mitigate negative environmental impacts [3]. In addition, with the improvement of living standards, Chinese diet is changing towards more meat consumption which drives maize production and livestock husbandry development $[4,5]$. Livestock excrement is likewise increasing substantially and more organic manure resources are available for farmers to use as organic fertilizer [5]. Farmyard manure has been considered as one of the efficient amendatory practices to alleviate the adverse impacts that chemical fertilizer caused, like soil quality degradation and acidification [6]. Furthermore, recycling livestock manure in agroecosystems could improve the crop yield, affect food security and reduce greenhouse gas emissions [7]. Numerous studies have shown that long-term application of organic manure in combination with mineral fertilizer application is beneficial for improving soil properties, such as soil organic matter [8,9], soil nutrient availability [6,10], soil infiltration [11] and subsequently crop yield [12-14]. However, few studies have conducted long-term experiments to estimate the effects of different animal manure application rates on crop production $[15,16]$.

We wonder whether the responses of maize yield to animal manure and mineral fertilizer, with the same amount of total applied macronutrients (N, P and K) are equal. In fact, there is a lack of such information in the scientific literature of studies that compare accumulated macronutrient $(\mathrm{N}, \mathrm{P}$ and $\mathrm{K})$ use efficiency, especially between organic and mineral fertilizer at different application rates in maize cropping systems. Therefore, we conducted a long-term experiment with organic manure and mineral fertilizer at the same nutrient input and four application levels. The objectives of the present study were to (1) observe maize yield under the different fertilizer treatments, (2) to evaluate the response of maize yield to two types of fertilizers (CM and MF) under the same amount of nutrient application rate and (3) to assess the effects of different fertilization regimes on accumulated nutrient use efficiency.

\section{Materials and Methods}

\subsection{Study Site}

A long-term field experiment (2008-2017) was implemented at the Quzhou County ( $36^{\circ} 52^{\prime} 21^{\prime \prime} \mathrm{N}$, $\left.115^{\circ} 01^{\prime} 20^{\prime \prime} \mathrm{E}\right)$, Hebei province in China. The site is characterized by a warm-temperate, sub-humid, continental and monsoonal climate. The annual mean precipitation is in the range of $500-700 \mathrm{~mm}$ (concentrated between July and September), and the average annual air temperature is $13.1{ }^{\circ} \mathrm{C}$. The monthly precipitation and temperature data for the site were collected from a nearby meteorological station and is presented in Figure 1. The soil type at the study site is classified as calcareous fluvo-aquic. To deplete plant available nutrients in the soil and to homogenize the experimental plot, prior to the start of the experiment, a winter wheat-summer maize rotation was grown for two years without any fertilization. The main physical and chemical properties of the soils at the top $20 \mathrm{~cm}$ layer are presented in Table 1. 


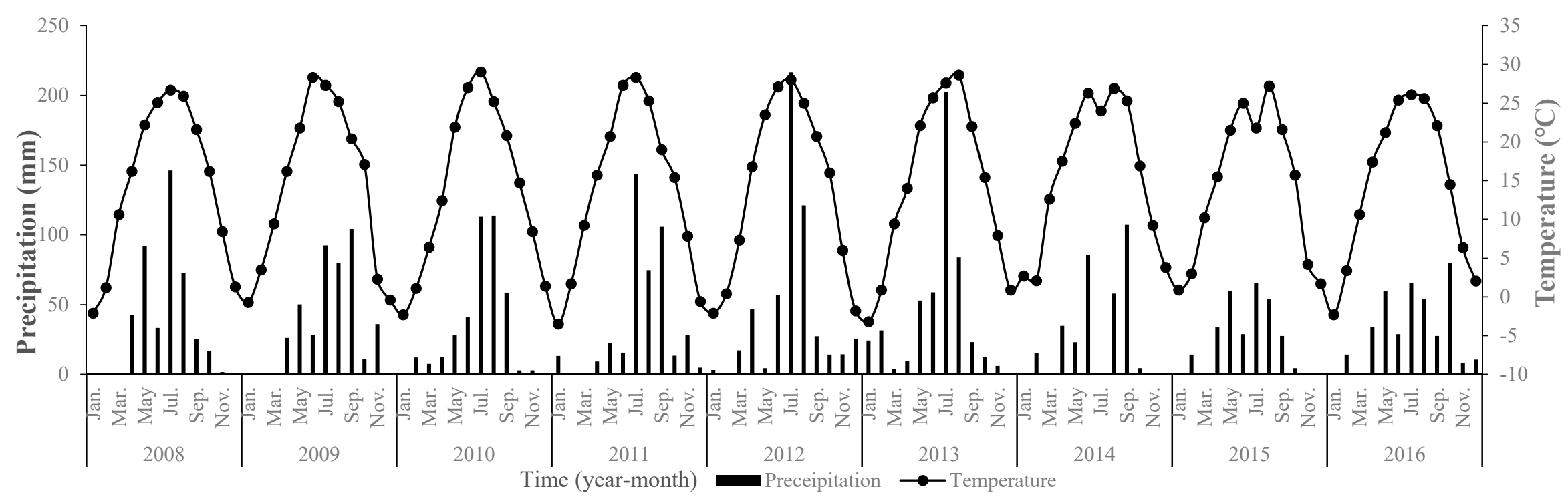

Figure 1. Monthly air temperature $\left({ }^{\circ} \mathrm{C}\right)$ and precipitation $(\mathrm{mm})$ at the experimental site in North China Plain region, China.

Table 1. Soil properties of the 0-20 cm top layer before the start of the experiment (2007).

\begin{tabular}{|c|c|c|c|c|c|c|c|}
\hline Soil Layer & Organic Matter & Total N & Total P & Total K & Olsen-P & Available K & $\mathrm{pH}$ \\
\hline $\mathrm{cm}$ & $\mathrm{g} \mathrm{kg}^{-1}$ & $\mathrm{~g} \mathrm{~kg}^{-1}$ & $\mathrm{~g} \mathrm{~kg}^{-1}$ & $\mathrm{~g} \mathrm{~kg}^{-1}$ & $\mathrm{mg} \mathrm{kg}^{-1}$ & $\mathrm{mg} \mathrm{kg}^{-1}$ & \\
\hline $0-20$ & 14.3 & 0.8 & 0.8 & 18.1 & 11.1 & 122.0 & 8.2 \\
\hline
\end{tabular}




\subsection{Experimental Design and Field Management}

Every year, four levels (3, 6, 9 and $12 \mathrm{t} \mathrm{DM} \mathrm{ha}^{-1}$ namely Level 1, Level 2, Level 3, Level 4, respectively) of solid CM were prepared (cow dung was fully dried, piled up and crushed to small patches) before sowing summer maize in June. Water and nutrient content (N, P and $\mathrm{K}$ ) of $\mathrm{CM}$ were measured with the method of Bao [17]. The equivalent amount of total N, P and $\mathrm{K}$ were replaced by a mineral fertilizer which is referred as MF. Nitrogen, phosphorus and potassium were applied as urea $(46 \%$ of $\mathrm{N})$, calcium superphosphate $\left(17.5 \%\right.$ of $\left.\mathrm{P}_{2} \mathrm{O}_{5}\right)$ and potassium sulfate $\left(5 \%\right.$ of $\left.\mathrm{K}_{2} \mathrm{O}\right)$, respectively. Detailed nutrient amount inputs at the four levels from year 2008 to 2017 are available in Table 2. In addition to these four pairs of fertilization treatments, we set-up a control treatment (CK) without any fertilizer application. In total, nine treatments using a randomized complete block design with three replications were established. The plot size was $10 \mathrm{~m} \times 10 \mathrm{~m}$. Before sowing of maize (cultivar "Zhengdan 958", predominantly cultivated in the region), the prepared CM was spread on the soil surface and then mixed into the 0 to $30 \mathrm{~cm}$ soil horizon with a deep plowing cultivator. All fertilizer treatments were applied manually. In CM treatments, cattle manure was applied as basal fertilizer before sowing of maize, while in mineral fertilizer treatments all the $P$ and $K$ fertilizer and $1 / 3$ amount of $\mathrm{N}$ was applied before sowing of maize as basal fertilizer and the remaining $2 / 3 \mathrm{~N}$ were applied at the maize jointing stage. After grain harvest, maize straw was crashed and returned back to the field with a rotary cultivator. This study used the local tillage and maize crop management practices and the crop was well irrigated as needed.

Table 2. Amount of nutrient inputs of the Level 1 treatment $\left(\mathrm{kg} \mathrm{ha}^{-1}\right)$.

\begin{tabular}{llllllllllll}
\hline Nutrient & $\mathbf{2 0 0 8}$ & $\mathbf{2 0 0 9}$ & $\mathbf{2 0 1 0}$ & $\mathbf{2 0 1 1}$ & $\mathbf{2 0 1 2}$ & $\mathbf{2 0 1 3}$ & $\mathbf{2 0 1 4}$ & $\mathbf{2 0 1 5}$ & $\mathbf{2 0 1 6}$ & $\mathbf{2 0 1 7}$ & Average \\
\hline $\mathrm{N}$ & 64.0 & 63.0 & 45.0 & 68.0 & 79.1 & 51.4 & 46.0 & 42.0 & 57.0 & 40.2 & 55.6 \\
$\mathrm{P}_{2} \mathrm{O}_{5}$ & 71.0 & 59.1 & 33.0 & 26.1 & 33.4 & 50.2 & 63.2 & 23.5 & 42.4 & 34.1 & 43.6 \\
$\mathrm{~K}_{2} \mathrm{O}$ & 82.1 & 59.1 & 67.0 & 48.0 & 32.4 & 42.2 & 54.2 & 28.3 & 52.5 & 37.7 & 50.4 \\
\hline
\end{tabular}

Level 1 corresponds to 3 cattle manure ha ${ }^{-1}$.

\subsection{Sampling and Measurements}

At harvest time each year, ten consecutive maize plants from the central row of each plot were manually cut close to the ground. Grain and straw were separated and all plant parts were oven-dried at $70{ }^{\circ} \mathrm{C}$ for $72 \mathrm{~h}$ to obtain grain and aboveground dry matter. Before lab analysis, grain and straw were ground with a Wiley mill using a $0.5 \mathrm{~mm}$ mesh. Plant samples were digested with $\mathrm{H}_{2} \mathrm{SO}_{4}-\mathrm{H}_{2} \mathrm{O}_{2}$ [18]. Total $\mathrm{N}$ concentration was determined according to Horowitz [19], total P concentration was measured by the vanadomolybdate yellow method [20] and total K concentration was determined by a flame spectrophotometer. All analyses were performed in duplicate. The plant macronutrient's composition was presented as nutrient concentration $\left(\mathrm{g} \mathrm{kg}^{-1}\right)$.

Soil samples were collected (30 cm depth increments from 0 to $90 \mathrm{~cm}$ ) in September 2017 from each plot with a manual auger (inner diameter $2 \mathrm{~cm}$ ). In order to obtain representative soil sample, three cores were taken from each plot and fully mixed to obtain one representative soil sample per plot. The soil samples were sieved field-moist though a $0.5 \mathrm{~cm}$ mesh, and one half was stored at $4{ }^{\circ} \mathrm{C}$ for measuring available $\mathrm{N}$ using a continuous flow analyzer (Seal-AA3, Seal Analytical $\mathrm{GmbH}$, Norderstedt, Germany). Another half of soil subsample were air-dried at room temperature and then passed through a $0.25 \mathrm{~cm}$ mesh for available phosphorus and potassium analysis with the methods of Olsen et al. [21] and Knudsen et al. [22]. For soil available N, we measured the three soil depth $(0-30 \mathrm{~cm}, 30-60 \mathrm{~cm}, 60-90 \mathrm{~cm})$, because $\mathrm{N}$ (as nitrate) is an easily movable nutrient in the soil profile and $\mathrm{N}$ below $90 \mathrm{~cm}$ soil depth has been considered as leaching. On the other hand, $\mathrm{P}$ and $\mathrm{K}$ are adsorbed at soil particles, and accumulate in the top soil $(0-30 \mathrm{~cm})$. 


\subsection{Calculation and Statistical Analysis}

The nutrients (N, P and K) uptake by maize (grain and straw) was computed as the product of the concentration multiplied by the dry weight of biomass.

Based on the annual amount of fertilizer applied and maize uptake during the 10 years, we estimated the accumulated nutrient use efficiency that included the accumulated partial factor productivity $\left(\mathrm{PFP}_{\mathrm{ac}}\right)$, the accumulated agronomic efficiency $\left(\mathrm{AE}_{\mathrm{ac}}\right)$ and the recovery efficiency $\left(\mathrm{RE}_{\mathrm{ac}}\right)$, with the following formulas $[23,24]$ :

$$
\begin{gathered}
\operatorname{PFP}_{\mathrm{ac}}(\mathrm{kg} / \mathrm{kg})=\frac{\sum_{1}^{n} Y}{\sum_{1}^{n} F} \\
\mathrm{AE}_{\mathrm{ac}}(\mathrm{kg} / \mathrm{kg})=\frac{\sum_{1}^{n} Y_{F}-\sum_{1}^{n} Y_{c k}}{\sum_{1}^{n} F} \\
\operatorname{REac}(\%)=\frac{\sum_{1}^{n} U_{F}-\sum_{1}^{n} U_{c k}}{\sum_{1}^{n} F} \times 100
\end{gathered}
$$

where $Y_{F}$ was the crop yield (dry weight) with the corresponding nutrient applied (N, P, K); $Y_{c k}$ was the yield of the control; $F$ represented the amount of nutrient applied. $U_{F}$ was the nutrient absorbed by the crops with the fertilizer treatments of this experiment; $U_{C K}$ represented the nutrient uptake in the aboveground crop biomass of CK. $\mathrm{N}$ is the number of year (10 years in the present study)

Statistical analyses were performed using Statistical Package for Windows (IBM SPSS statistics for Windows, Version 22; IBM Corporation Armonk, NY, USA). Normality and homogeneity of variance were tested by the Shapiro-Wilk method before variance analysis, and no significant outliers were detected. For the results of crop yield and yield component from each year, accumulated nutrients use efficiency, and soil nutrient content, one-way analysis of variance was used. For nutrients' contents and uptakes results, mixed models were used for analysis of variance, with fertilizer treatment as a fixed effect, year as random effects. Treatment means were compared using Duncan at 0.05 level of probability when the main effect was significant.

\section{Results}

\subsection{Grain Yield}

Ten years data showed that maize grain yields were significantly affected by fertilizer treatments, year and their interaction (Table S1). In the first experimental year, maize with MF showed a significantly higher grain yield than with maize using CM. The yields of MF treatments were $31.1 \%$, $38.8 \%, 25.0 \%$ and $18.4 \%$ higher (under Levels 1, 2, 3 and 4, respectively) compared to CM treatments (Figure 2). Furthermore, in the year 2008, maize yield was significantly increased with increased fertilizer rates for both MF and CM treatments. Grain yields under the fertilizer Levels 1, 2, 3 and 4 fertilizer treatments were significantly higher than in the control treatment (CK) by $42.7 \%, 80.7 \%$, $126.8 \%$ and $132.6 \%$, respectively. In 2009, the second year of the experiment, maize with MF applications at fertilizer Levels 1 and 2 exhibited superior yields in comparison with CM applications. However, when higher fertilizers levels (Level 3 and Level 4) were applied, CM treatments exhibited better grain yields than MF treatments. Increasing CM rates, significantly increased grain yield (up to Level 3), but no significant yield differences were found for the four MF rates. From the year 2010 (the third year of the experiment) onward no significant differences on grain yield between MF and CM treatments for a given nutrient level were found (except 2014 Level 2 and 2017 Level 3). In addition, increasing MF rate did not result in increases of maize yields during the subsequent 8 years of the experiment. Nevertheless, raise CM rate from Level 1 to Level 4 continuously enhanced the maize yield in the first 8 years but with exception in 2013. However, these differences were not significant in the last two years of the experiment. The 10-year average data showed that grain yield of summer maize significantly increased by using MF and CM in comparison to no-fertilizer applications (CK). This response might result from the differences observed in the yield components across fertilizer types (Table 3). In general, there were no significant differences of maize yield between MF and CM, and the response of grain 
yield to increased amount of $\mathrm{MF}$ and $\mathrm{CM}$ were similar. However, the minimum $\mathrm{N}$ rates required to achieve the maximum grain yield were different between the MF and CM treatments. In comparison with $\mathrm{MF}$, more $\mathrm{N}$ from the $\mathrm{CM}$ is needed to achieve the maximum crop yields.

Table 3. Maize yield components in response to two types of fertilizers (CM and MF) and four application levels.

\begin{tabular}{|c|c|c|c|c|c|c|c|c|c|}
\hline & & Level 1 & & Level 2 & & Level 3 & & Level 4 & \\
\hline Year & CK & CM & MF & $\mathrm{CM}$ & MF & $\mathrm{CM}$ & MF & CM & MF \\
\hline \multicolumn{10}{|c|}{ 1000-kernel weight (g) } \\
\hline 2008 & $207.6^{b}$ & $213.1^{b}$ & $246.4^{\mathrm{a}}$ & $226.1^{a, b}$ & $255.2^{\mathrm{a}}$ & $250.9^{a}$ & $255.4^{\mathrm{a}}$ & $241.2^{\mathrm{a}}$ & $248.6^{a}$ \\
\hline 2009 & 227.2 & 244.2 & 260.8 & 252.2 & 263.4 & 262.7 & 256.4 & 256.3 & 265.1 \\
\hline 2010 & $247.2^{b}$ & $269.2^{\mathrm{a}, \mathrm{b}}$ & $289.8^{a}$ & $275.4^{\mathrm{a}, \mathrm{b}}$ & $278.4^{\mathrm{a}, \mathrm{b}}$ & $270.9^{a, b}$ & $259.9^{a, b}$ & $261.4^{\mathrm{a}, \mathrm{b}}$ & $270^{a, b}$ \\
\hline 2011 & $236.1^{d}$ & $246.8^{b, c, d}$ & $251.1^{a, b, c}$ & $243.2^{c, d}$ & $255.1^{a, b, c}$ & $258.4^{\mathrm{a}, \mathrm{b}}$ & $262.6^{\mathrm{a}}$ & $255.8^{a, b, c}$ & $264.6^{\mathrm{a}}$ \\
\hline 2012 & $233.2^{c}$ & $264.2^{b}$ & $273.7^{\mathrm{a}, \mathrm{b}}$ & $281.3^{a, b}$ & $282.6^{a, b}$ & $288.6^{a, b}$ & $264.8^{\mathrm{a}}$ & $283.9^{a, b}$ & $295.2^{\mathrm{a}}$ \\
\hline 2013 & 224.6 & 225.0 & 221.5 & 228.7 & 208.4 & 220.4 & 207.5 & 214.7 & 214.0 \\
\hline 2014 & $240.1^{b}$ & $266.4^{a}$ & $267.2^{a}$ & $271.4^{\mathrm{a}}$ & $261.7^{\mathrm{a}}$ & $264.1^{a}$ & $268.3^{a}$ & $263.7^{a}$ & $269.1^{a}$ \\
\hline 2015 & $230.0^{c}$ & $255.7^{b}$ & $259.5^{\mathrm{a}, \mathrm{b}}$ & $275.5^{\mathrm{a}}$ & $270.2^{a, b}$ & $263.0^{a, b}$ & $277.0^{\mathrm{a}}$ & $256.2^{b}$ & $276^{a}$ \\
\hline 2016 & 247.0 & 266.1 & 280.3 & 249.4 & 263.5 & 252.2 & 275.9 & 248.5 & 250.0 \\
\hline 2017 & 270.1 & 282.8 & 280.5 & 301.5 & 275.2 & 295.5 & 294.6 & 293.6 & 297.9 \\
\hline mean & 237.3 & 254.4 & 263.3 & 261.4 & 261.1 & 262.7 & 262.9 & 257.7 & 265.0 \\
\hline \multicolumn{10}{|c|}{ Kernel number per ear } \\
\hline 2008 & $362^{b}$ & $432^{a}$ & $433^{a}$ & $462^{\mathrm{a}}$ & $479^{a}$ & $480^{\mathrm{a}}$ & $466^{\mathrm{a}}$ & $499^{a}$ & $460^{\mathrm{a}}$ \\
\hline 2009 & $272^{d}$ & $340.5^{c}$ & $359^{b, c}$ & $407^{\mathrm{a}, \mathrm{b}}$ & $407^{\mathrm{a}, \mathrm{b}}$ & $432^{a}$ & $426^{a}$ & $433^{a}$ & $427^{\mathrm{a}}$ \\
\hline 2010 & $432^{c}$ & $452^{b, c}$ & $444^{b, c}$ & $485^{\mathrm{a}, \mathrm{b}, \mathrm{c}}$ & $490^{a, b}$ & $500^{\mathrm{ab}}$ & $491^{\mathrm{a}, \mathrm{b}}$ & $515^{a}$ & $478^{a, b, c}$ \\
\hline 2011 & $395^{b}$ & $471^{\mathrm{a}}$ & $479^{a}$ & $488^{a}$ & $472^{\mathrm{a}}$ & $475^{a}$ & $478^{a}$ & $483^{a}$ & $464^{\mathrm{a}}$ \\
\hline 2012 & $263^{d}$ & $393^{c}$ & $398^{c}$ & $437^{b, c}$ & $498^{a, b}$ & $490^{a, b}$ & $453^{a, b, c}$ & $523^{a}$ & $463^{a, b, c}$ \\
\hline 2013 & $308^{c}$ & $397^{b}$ & $418^{b, c}$ & $440^{\mathrm{a}, \mathrm{b}}$ & $465^{\mathrm{a}}$ & $470^{\mathrm{a}}$ & $447^{\mathrm{a}, \mathrm{b}}$ & $477^{\mathrm{a}}$ & $446^{\mathrm{a}, \mathrm{b}}$ \\
\hline 2014 & $278^{c}$ & $365^{b}$ & $366^{b}$ & $420^{a, b}$ & $441^{\mathrm{a}}$ & $475^{\mathrm{a}}$ & $460^{\mathrm{a}}$ & $462^{\mathrm{a}}$ & $489^{a}$ \\
\hline 2015 & $243^{d}$ & $277^{c, d}$ & $313^{b, c}$ & $380^{a, b}$ & $336^{a, b, c}$ & $373^{a, b}$ & $391^{a}$ & $381^{a, b}$ & $368^{a, b}$ \\
\hline 2016 & $350^{c}$ & $477^{\mathrm{a}, \mathrm{b}}$ & $463^{b}$ & $518^{a, b}$ & $485^{\mathrm{a}, \mathrm{b}}$ & $505^{a, b}$ & $505^{a, b}$ & $474^{\mathrm{a}, \mathrm{b}}$ & $531^{a}$ \\
\hline 2017 & 293 & 337 & 318 & 329 & 345 & 374 & 335 & 310 & 357 \\
\hline mean & 320 & 396 & 400 & 437 & 442 & 458 & 445 & 453 & 450 \\
\hline \multicolumn{10}{|c|}{ Harvest ear density } \\
\hline 2011 & 7.13 & 7.48 & 7.44 & 7.44 & 7.43 & 7.3 & 7.07 & 7.46 & 7.41 \\
\hline 2012 & 7.31 & 7.20 & 7.45 & 7.53 & 7.34 & 7.34 & 7.42 & 7.31 & 7.48 \\
\hline 2013 & 6.97 & 6.58 & 6.67 & 6.17 & 6.61 & 5.97 & 6.44 & 6.56 & 6.53 \\
\hline 2014 & $7.67^{a, b}$ & $8.03^{a}$ & $7.94^{\mathrm{a}}$ & $7.17^{c}$ & $7.56^{\mathrm{a}, \mathrm{b}, \mathrm{c}}$ & $7.83^{b, c}$ & $7.42^{a, b}$ & $7.69^{a, b}$ & $7.58^{a, b, c}$ \\
\hline 2015 & 7.47 & 7.42 & 7.47 & 7.14 & 6.86 & 7.36 & 7.22 & 7.33 & 6.92 \\
\hline 2016 & 7.92 & 7.50 & 7.28 & 7.47 & 7.25 & 7.72 & 7.31 & 7.64 & 7.81 \\
\hline 2017 & $7.81^{\mathrm{a}}$ & $7.64^{a, b}$ & $7.86^{a}$ & $7.78^{\mathrm{a}}$ & $6.98 \mathrm{~b}$ & $7.84^{\mathrm{a}}$ & $7.34^{\mathrm{a}, \mathrm{b}}$ & $7.20^{a, b}$ & $7.28^{a, b}$ \\
\hline mean & 7.47 & 7.41 & 7.44 & 7.24 & 7.15 & 7.34 & 7.17 & 7.31 & 7.29 \\
\hline
\end{tabular}

Note: CK: Control treatment (non-fertilized); CM: cattle manure; MF: mineral fertilizer; Level 1 corresponding to $3 \mathrm{tCM} \mathrm{ha}^{-1}$, Level 2 to $6 \mathrm{tCM} \mathrm{ha}^{-1}$, Level 3 to $9 \mathrm{t} \mathrm{CM} \mathrm{ha}^{-1}$, Level 4 to $12 \mathrm{tCM} \mathrm{ha}^{-1}$. Different lowercase letters indicate statistical differences $(p \leq 0.05)$ among fertilizer treatments, letters are not provided when no differences between treatments were found. 


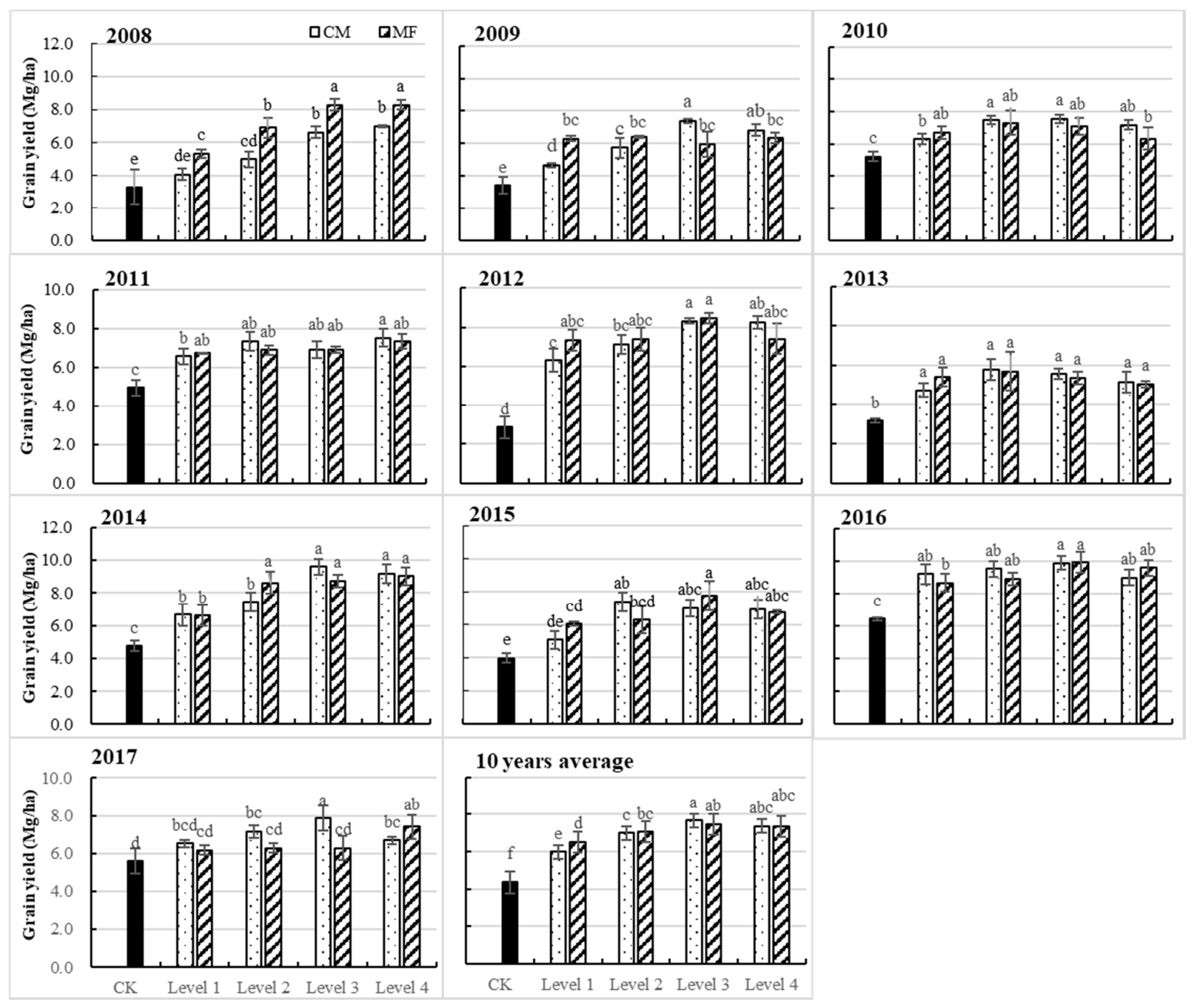

Figure 2. Maize yields observed under two types of fertilizer and four application levels along a 10-year field experiment (2008-2017) at North China Plain region, China. CK: Control treatment (non-fertilized); CM: cattle manure; MF: mineral fertilizer; Level 1 corresponding to $3 \mathrm{t} \mathrm{CM} \mathrm{ha}^{-1}$, Level 2 to $6 \mathrm{t} \mathrm{CM} \mathrm{ha}^{-1}$, Level 3 to $9 \mathrm{tCM} \mathrm{ha}^{-1}$, Level 4 to $12 \mathrm{t} \mathrm{CM} \mathrm{ha}^{-1}$. Error bars are standard error of three replicates. Different lowercase letters indicate statistical differences $(p \leq 0.05)$ among fertilizer treatments. 


\subsection{Nutrient Content}

The average $\mathrm{N}$ and $\mathrm{P}$ content in grain ranged within $9.32-12.88 \mathrm{~g} \mathrm{~kg}^{-1}$ and $2.41-2.73 \mathrm{~g} \mathrm{~kg}^{-1}$ and were significantly higher than the $\mathrm{N}$ and $\mathrm{P}$ contents in straw, which ranged between $9.26-5.24 \mathrm{~g} \mathrm{~kg}^{-1}$ and $0.67-1.28 \mathrm{~g} \mathrm{~kg}^{-1}$ (Table 4). K content in maize straw ranged from 14.06 to $20.67 \mathrm{~g} \mathrm{~kg}^{-1}$ and was remarkably greater than $\mathrm{K}$ contents in grain $\left(2.44-2.58 \mathrm{~g} \mathrm{~kg}^{-1}\right.$ ) (Table 4). The $\mathrm{N}$ contents in grain and straw increased with the addition of MF and CM. Among all treatments, maize fertilized with MF at the highest level (Level 4) had the maximum N contents in the different plant parts. However, differences between the grain N content of MF and CM at Level 4 were not apparent. Conversely, $\mathrm{P}$ contents in grain and straw did not show significant changes with increasing $\mathrm{CM}$ and MF rates. Maize using CM displayed superior grain and straw $\mathrm{P}$ content than the maize that received MF applications, this response was different to the one observed with $\mathrm{N}$. Although applying MF and CM could increase grain K content, no statistical differences were observed between fertilizer treatments. The K content of straw increased with increasing MF and CM application, but no evident differences have been found between MF and CM.

Table 4. Average N, P and $\mathrm{K}$ contents and uptakes in maize in response to different fertilization treatments over 10 years.

\begin{tabular}{|c|c|c|c|c|c|c|c|c|c|c|}
\hline \multirow{3}{*}{ Item } & \multirow{3}{*}{$\begin{array}{c}\text { Plant } \\
\text { Part }\end{array}$} & & \multicolumn{8}{|c|}{ Treatments } \\
\hline & & \multirow{2}{*}{ CK } & \multicolumn{2}{|c|}{ Level 1} & \multicolumn{2}{|c|}{ Level 2} & \multicolumn{2}{|c|}{ Level 3} & \multicolumn{2}{|c|}{ Level 4} \\
\hline & & & $\mathrm{CM}$ & MF & $\mathrm{CM}$ & MF & $\mathrm{CM}$ & MF & $\mathrm{CM}$ & MF \\
\hline $\mathrm{N}$ content & Grain & $9.32^{f}$ & $10.05^{\mathrm{e}, \mathrm{f}}$ & $10.51^{\mathrm{d}, \mathrm{e}}$ & $11.12^{\mathrm{c}, \mathrm{d}}$ & $11.81^{b, c}$ & $11.74^{\mathrm{b}, \mathrm{c}}$ & $12.63^{a, b}$ & $12.45^{\mathrm{a}, \mathrm{b}}$ & $12.88^{\mathrm{a}}$ \\
\hline$\left(\mathrm{g} \mathrm{kg}^{-1}\right)$ & Straw & $5.24^{\mathrm{h}}$ & $5.79 \mathrm{~g}, \mathrm{~h}$ & $6.19^{\mathrm{f}, \mathrm{g}}$ & $6.81 \mathrm{e}, \mathrm{f}$ & $7.74^{\mathrm{c}, \mathrm{d}}$ & $7.06^{\mathrm{d}, \mathrm{e}}$ & $8.56^{\mathrm{a}, \mathrm{b}}$ & $8.11^{b, c}$ & $9.26^{\mathrm{a}}$ \\
\hline $\mathrm{N}$ uptake & Grain & $41.31^{\mathrm{f}}$ & $61.60^{\mathrm{e}}$ & $68.92^{\mathrm{d}, \mathrm{e}}$ & $78.48^{\mathrm{c}, \mathrm{d}}$ & $83.39^{b, c}$ & $90.16^{a, b}$ & $93.58^{a, b}$ & $91.35^{\mathrm{a}, \mathrm{b}}$ & $94.39^{a}$ \\
\hline$\left(\mathrm{kg} \mathrm{ha}^{-1}\right)$ & Straw & $25.83^{\mathrm{g}}$ & $37.78^{f}$ & $40.93^{\mathrm{e}, \mathrm{f}}$ & $49.26^{\mathrm{d}, \mathrm{e}}$ & $58.42^{c, d}$ & $51.29^{\mathrm{c}, \mathrm{d}}$ & $70.43^{a}$ & $60.58^{b, c}$ & $69.21^{a, b}$ \\
\hline P content & Grain & $2.54^{\mathrm{a}, \mathrm{b}}$ & $2.73^{a}$ & $2.42^{b}$ & $2.56^{a, b}$ & $2.41^{a, b}$ & $2.67^{a, b}$ & $2.53^{a, b}$ & $2.68^{a, b}$ & $2.54^{\mathrm{a}, \mathrm{b}}$ \\
\hline$\left(\mathrm{g} \mathrm{kg}^{-1}\right)$ & Straw & $1.03^{\mathrm{b}}$ & $1.28^{\mathrm{a}}$ & $0.67^{\mathrm{d}}$ & $0.92^{b, c}$ & $0.78^{c, d}$ & $0.98^{b, c}$ & $0.76^{\mathrm{c}, \mathrm{d}}$ & $0.96^{b, c}$ & $0.82^{b, c, d}$ \\
\hline P uptake & Grain & $10.91^{\mathrm{e}}$ & $16.53^{c, d}$ & $15.77^{\mathrm{d}}$ & $17.70^{b, c, d}$ & $\begin{array}{l}17.02 \\
b, c, d\end{array}$ & $20.48^{a}$ & $\begin{array}{l}19.01 \\
a, b, c\end{array}$ & $19.65^{a, b}$ & $\begin{array}{l}18.78 \\
a, b, c\end{array}$ \\
\hline$\left(\mathrm{kg} \mathrm{ha}^{-1}\right)$ & Straw & $4.77^{\mathrm{c}, \mathrm{d}}$ & $7.83^{a}$ & $4.38^{c, d}$ & $6.11^{b, c}$ & $5.87^{b, c}$ & $6.63^{a, b}$ & $6.31^{b}$ & $6.85^{a, b}$ & $6.12^{b, c}$ \\
\hline K content & Grain & 2.44 & 2.55 & 2.49 & 2.46 & 2.56 & 2.44 & 2.54 & 2.50 & 2.58 \\
\hline$\left(\mathrm{g} \mathrm{kg}^{-1}\right)$ & Straw & $14.06^{\mathrm{e}}$ & $15.88^{\mathrm{d}, \mathrm{e}}$ & $15.80^{\mathrm{d}, \mathrm{e}}$ & $17.87^{b, c, d}$ & $17.51^{\mathrm{c}, \mathrm{d}}$ & $\begin{array}{l}18.42 \\
a, b, c, d\end{array}$ & $\begin{array}{l}19.28 \\
a, b, c\end{array}$ & $20.30^{a, b}$ & $20.67^{a}$ \\
\hline K uptake & Grain & $10.80^{b}$ & $15.49^{a}$ & $16.10^{\mathrm{a}}$ & $17.30^{\mathrm{a}}$ & $18.13^{\mathrm{a}}$ & $18.72^{\mathrm{a}}$ & $19.41^{\mathrm{a}}$ & $18.49^{a}$ & $19.60^{\mathrm{a}}$ \\
\hline$\left(\mathrm{kg} \mathrm{ha}^{-1}\right)$ & Straw & $70.12^{\mathrm{e}}$ & $101.7^{\mathrm{d}}$ & $107.97^{c, d}$ & $125.72^{b, c, d}$ & $130.75^{b, c}$ & $\begin{array}{l}130.82 \\
\mathrm{a}, \mathrm{b}\end{array}$ & $160.10^{a}$ & $\begin{array}{l}149.40 \\
\mathrm{a}, \mathrm{b}\end{array}$ & $\begin{array}{l}150.65 \\
a, b\end{array}$ \\
\hline
\end{tabular}

CK: Control treatment (non-fertilized); CM: cattle manure; MF: synthetic fertilizer; Level 1 corresponding to $3 \mathrm{tCM} \mathrm{ha} a^{-1}$, Level 2 to $6 \mathrm{t} \mathrm{CM} \mathrm{ha}^{-1}$, Level 3 to $9 \mathrm{tCM} \mathrm{ha}^{-1}$, Level 4 to $12 \mathrm{t} \mathrm{CM} \mathrm{ha}^{-1}$. Different letters represent significance groups $(p \leq 0.05)$, letters are not provided when no differences between treatments were found.

\subsection{Nutrients Uptake}

Compared with the control treatment (CK), the 10-year average data show that MF and CM applications led to a significant increase in aboveground N, P and K uptake (Table 4). Similar to the pattern of the nutrient contents, Table 4 shows that the average $\mathrm{N}$ and $\mathrm{P}$ uptake in the grain was higher than in the straw, but straw $\mathrm{K}$ uptake was 6.4-8.2 times higher than the grain $\mathrm{K}$ uptake. Aboveground $\mathrm{N}$ uptake ranges from 67.14 to $164.82 \mathrm{~kg} \mathrm{ha}^{-1}$ which was similar to aboveground $\mathrm{K}$ uptake (80.93-179.51 kg ha-1), whereas P uptake (15.29-28.31 kg ha ${ }^{-1}$ ) was significantly lower than $\mathrm{N}$ and $\mathrm{K}$. Maize with MF treatments exhibited notably higher aboveground $\mathrm{N}$ uptakes than $\mathrm{CM}$ treatments at all levels of fertilizer rates. At Level 1 of fertilization, grain $\mathrm{N}$ content with $\mathrm{MF}$ was considerably higher than that of CM. However, no clear differences were found between MF and CM in the other three fertilizer input levels (Levels 2, 3 and 4). Contrasting with grain $\mathrm{N}$ content, the straw content under MF treatments were significantly higher than that under CM treatments, with exception at Level 1 fertilizer rate. Similarly to the $\mathrm{N}$ contents, the grain and straw $\mathrm{N}$ uptake increased with increasing fertilizer rates for both MF and CM. Grain, straw and aboveground P uptakes under the CM treatments were higher than under MF treatments, however, these differences were significant only for 
straw P uptake with the lowest fertilization level (Level 1). No considerable difference of P contents in grain and straw was found between MF and CM treatment at Level 2, Level 3 and Level 4 fertilizer rates. Comparing to $\mathrm{CK}$, application of MF and CM could significantly improve the grain, straw and aboveground $\mathrm{P}$ uptake to different extents. The aboveground $\mathrm{P}$ uptake increased with increasing fertilizer rate for both MF and CM treatments. Generally, no significant differences of grain, straw and aboveground $\mathrm{K}$ uptake were obtained between MF and CM treatments in all fertilizer application levels. However, increasing the fertilizer rate significantly increased the grain, straw and aboveground K uptake.

\subsection{Accumulated Nutrients Use Efficiencies}

In this study, 10-year field data were used to estimate the accumulated nutrients ( $\mathrm{N}, \mathrm{P}$ and $\mathrm{K}$ ) use efficiencies including $\mathrm{PFP}_{\mathrm{ac}}, \mathrm{AE}_{\mathrm{ac}}$ and $\mathrm{RE}_{\mathrm{ac}}$. Our results showed that $\mathrm{N}, \mathrm{P}$ and $\mathrm{K}$ use efficiencies containing $\mathrm{PFP}_{\mathrm{ac}}, \mathrm{AE}_{\mathrm{ac}}$ and $\mathrm{RE}_{\mathrm{ac}}$ were in a clear decreasing trend with increasing fertilizer rates for both $\mathrm{MF}$ and $\mathrm{CM}$ treatments (Figure 3). However, $\mathrm{PFP}_{\mathrm{ac}}, \mathrm{AE}_{\mathrm{ac}}$ and $\mathrm{RE}_{\mathrm{ac}}$ displayed differently for studied macronutrients. For phosphor, $\mathrm{PFP}_{\mathrm{ac}}$ ranged $108.4-393.3 \mathrm{~kg} / \mathrm{kg}$, which was significantly higher than that of nitrogen (34.5-122.2 $\mathrm{kg} \mathrm{kg}^{-1}$ ) and potassium (47.9-172.4 $\mathrm{kg} \mathrm{kg}^{-1}$ ). Similar to $\mathrm{AE}_{\mathrm{ac}}$, the value of $\mathrm{AE}_{\mathrm{Pac}}$ was also statistically higher than $\mathrm{AE}_{\mathrm{Nac}}$ and $\mathrm{AE}_{\mathrm{Kac}}$. However, $\mathrm{RE}_{\mathrm{Pac}}$ ranges from $13.5 \%$ to $53.6 \%$ were lower than $\mathrm{RE}_{\mathrm{Kac}}$ ranges $(58.2-113.0 \%)$ and $\mathrm{RE}_{\mathrm{Nac}}$ ranges $(39.7-78.7 \%)$ (Figure 3).

Applying the same amount of nutrient with different fertilizer types (MF and CM) at different levels affected the nutrient use efficiencies at different extents. At Level 1 of fertilization, the $\mathrm{PFP}_{\mathrm{ac}}$ and $\mathrm{AE}_{\mathrm{ac}}$ of all the nutrients (N, $\mathrm{P}$ and $\mathrm{K}$ ) with $\mathrm{MF}$ treatments were significantly higher than that with $\mathrm{CM}$ treatment. However, increasing fertilizer input levels (Levels 2, 3 and 4) with CM, resulted in slightly higher $\mathrm{PFP}_{\mathrm{ac}}$ and $\mathrm{AE}_{\mathrm{ac}}$ values for all the nutrients compared with values of MF treatments. The $\mathrm{RE}_{\mathrm{ac}}$ of N, $\mathrm{P}$ and $\mathrm{K}$ performed differently in MF and CM treatments. Maize with MF applications exhibited higher $\mathrm{RE}_{\mathrm{Nac}}$ than that with $\mathrm{CM}$ applications. However, higher $\mathrm{RE}_{\mathrm{Pac}}$ was found in $\mathrm{CM}$ treatments rather than $M F$ treatments at all fertilizer rates, especially at Level 1. Generally, no apparent differences of $\mathrm{RE}_{\mathrm{Kac}}$ were found between $\mathrm{CM}$ and MF treatments.

\subsection{Soil Nutrients}

Soil $\mathrm{NO}_{3}-\mathrm{N}$, available $\mathrm{P}$ and $\mathrm{K}$ content showed a significant increase as fertilizer rate level increased (Figures 4 and 5). Soil $\mathrm{NO}_{3}-\mathrm{N}$ increased from 4.5 to $39.6 \mathrm{mg} \mathrm{kg}^{-1}$ at the $0-30 \mathrm{~cm}$ soil layers. No significant difference of soil $\mathrm{NO}_{3}-\mathrm{N}$ and available $\mathrm{K}$ was found between $\mathrm{CM}$ and $\mathrm{MF}$ at the $0-30 \mathrm{~cm}$ soil layer. However, at deeper layers $(30-60 \mathrm{~cm}$ and $60-90 \mathrm{~cm}$ ) and under higher fertilizer rates (Level 3 and Level 4), $\mathrm{NO}_{3}-\mathrm{N}$ in the MF treatments were significantly higher than in the $\mathrm{CM}$ treatments. This study also found that at $0-30 \mathrm{~cm}$ soil layer, soil available P in CM treatments were higher than in MF treatments. These results showed that the application of organic fertilizer (CM) adds significantly more available $\mathrm{P}$ content to the soil than the application of mineral fertilizer (MF). 


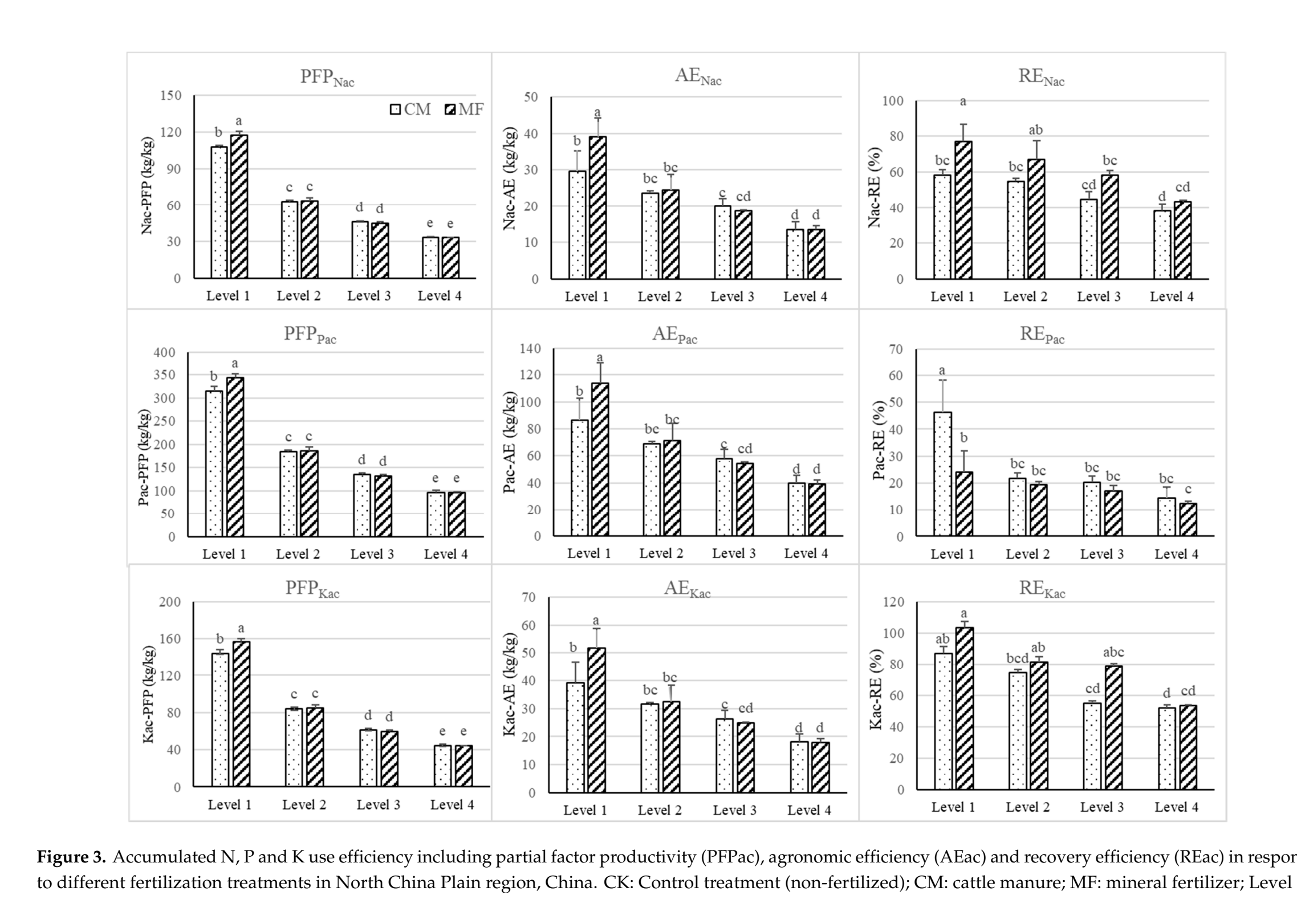


corresponding to $3 \mathrm{t} \mathrm{CM} \mathrm{ha}{ }^{-1}$, Level 2 to $6 \mathrm{t} \mathrm{CM} \mathrm{ha}^{-1}$, Level 3 to $9 \mathrm{t} \mathrm{CM} \mathrm{ha}^{-1}$, Level 4 to $12 \mathrm{t} \mathrm{CM} \mathrm{ha}{ }^{-1}$. Error bars are standard error of three replicates. Different lowercase letters indicate statistical differences $(p \leq 0.05)$ among fertilizer treatments.

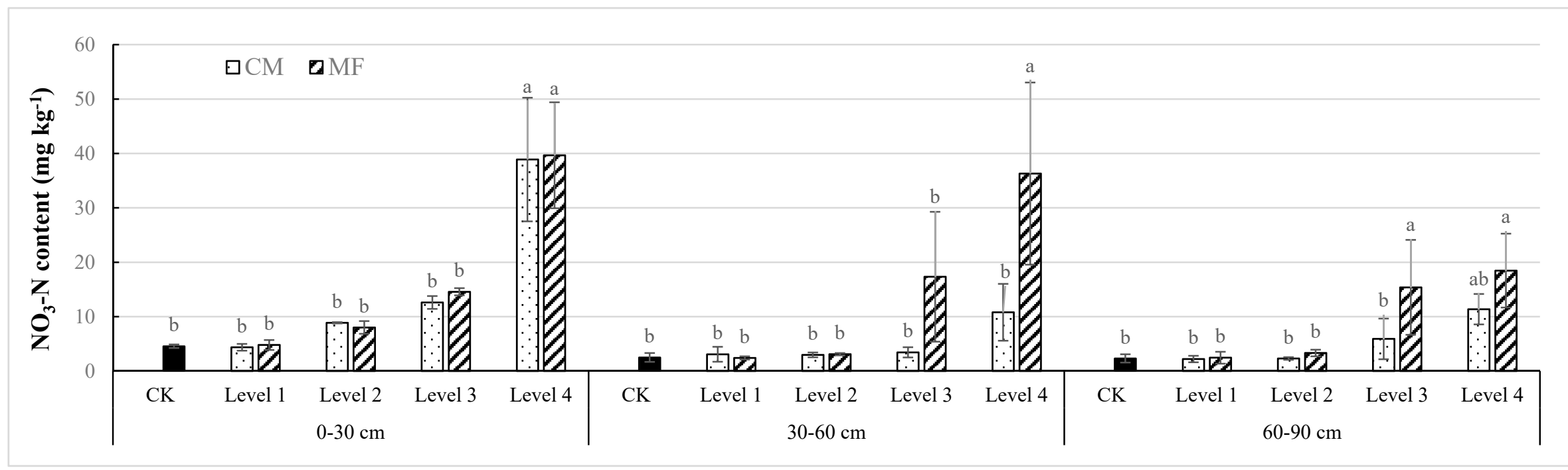

Figure 4. Soil nitrate nitrogen $\left(\mathrm{NO}_{3}-\mathrm{N}\right)$ content at $0-30 \mathrm{~cm}, 30-60 \mathrm{~cm}, 60-90 \mathrm{~cm}$ soil depth under two different types of fertilizer at four different rate levels. CK: Control treatment (non-fertilized); CM: cattle manure; MF: mineral fertilizer; Level 1 corresponding to $3 \mathrm{t} \mathrm{CM} \mathrm{ha}^{-1}$, Level 2 to $6 \mathrm{t}$ CM ha ${ }^{-1}$, Level 3 to $9 \mathrm{t}$ CM ha ${ }^{-1}$, Level 4 to $12 \mathrm{t} \mathrm{CM} \mathrm{ha}^{-1}$. Lowercase letters indicate significance groups for nitrate nitrogen contents within each level of the tested fertilizers ( $p \leq 0.05$ ). Error bars are standard error of three replicates. Different lowercase letters indicate statistical differences $(p \leq 0.05)$ among fertilizer treatments. 

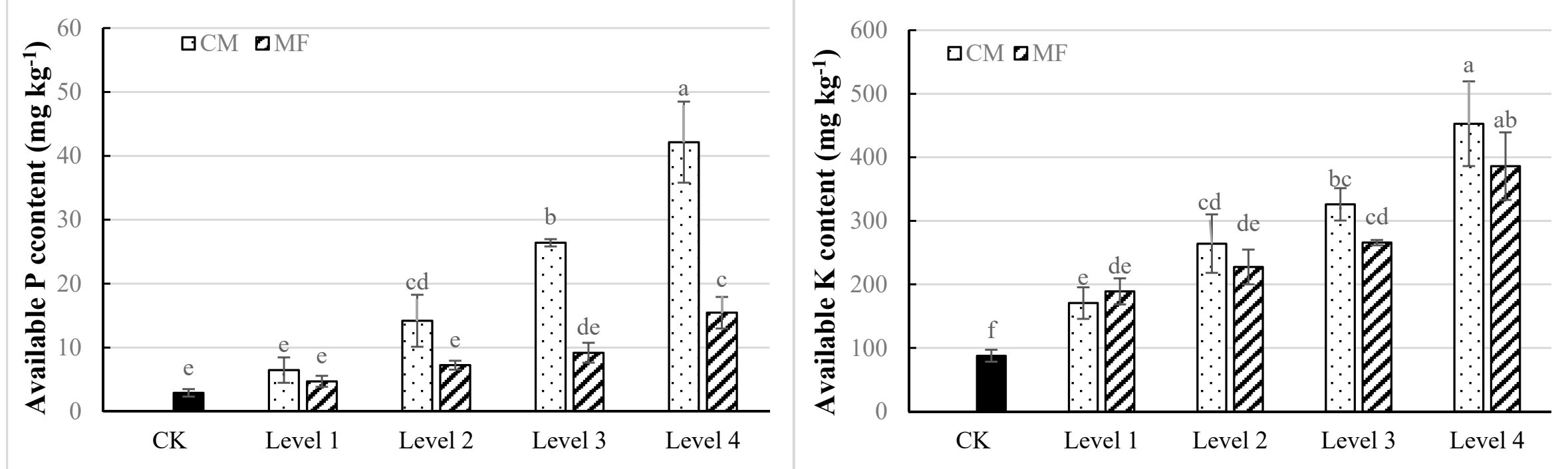

Figure 5. Soil available $\mathrm{P}$ and $\mathrm{K}$ of 0-30 cm soil layer under two types of fertilizer at four application levels CK: Control treatment (non-fertilized); CM: cattle manure; MF: mineral fertilizer; Level 1 corresponding to $3 \mathrm{t} \mathrm{CM} \mathrm{ha}^{-1}$, Level 2 to $6 \mathrm{t} \mathrm{CM} \mathrm{ha}^{-1}$, Level 3 to $9 \mathrm{t} \mathrm{CM} \mathrm{ha}^{-1}$, Level 4 to $12 \mathrm{t} \mathrm{CM} \mathrm{ha}{ }^{-1}$. Error bars are standard error of three replicates. Different lowercase letters indicate statistical differences $(p \leq 0.05)$ among fertilizer treatments. 


\section{Discussion}

\subsection{Response of Yield to Fertilizer Treatments}

This long-term study revealed that significantly higher maize yields were obtained with MF and $\mathrm{CM}$ compared with the control treatment $(\mathrm{CK})$. Numerous studies also reported that manure and mineral fertilizer could improve the crop yield in China $[10,25,26]$. However, our study found that the fertilizer type (organic vs. inorganic) did not alter maize yield when the equal amount of major nutrient was applied over 10 years. These results are in agreement with Xin et al. [27] who reported that 20-year grain yield averages between mineral fertilizer and compost treatments were similar. However, the first harvest (2008) showed significantly higher grain yields for MF compared to CM treatments. These differences narrowed with time. As a result that most of the nutrients in CM treatments were organically bounded and slowly released compared to MF treatments, nutrients provided from the soil in CM treatments would not keep up with the nutrients demand of maize $[15,28]$. In later periods of the long-term experiment, more available nutrients in manure were released and the yield gap between MF and CM narrowed. In the last years of the experiment, maize with CM showed slightly higher grain yield than maize with MF. Long-term CM application may improve soil properties, soil structure and micro-biological activity, thus enhance the nutrients retention and absorption capacity of crop roots [6,29,30]. Our findings are consistent with reports from Zhang et al. [31] who also demonstrated that the effect of full MF substitution by manure on crop yield becomes non-significant with an increased duration of the experiment. Fan et al. [32] through model simulation and field experiments in Denmark also reported increasing crop yield with increasing number of years under organic farming management. Our study also found that increased yield by CM compared to MF was greater on the long term than on the short term. These results are consistent with experiments in Japan [33]. However, this study also demonstrated that as the fertilizer rate increases, effects of fertilizer type on crop yield become smaller to non-significant, especially at the highest rate when sufficient nutrients might have been already supplied for growth. These results are in agreement with Zhang et al. [31].

\subsection{Accumulated Nutrients Use Efficiencies}

Nutrient use efficiencies are meaningful for the nutrient cycle. Most studies focused on comparing nitrogen use efficiency (NUE) between MF and partial substitution of MF by manure [34,35]. Vanlauwe et al. [35] reported that maize annual nitrogen agronomic efficiency (NAE) increased from $25 \mathrm{~kg} \mathrm{~kg}^{-1}$ to $38 \mathrm{~kg} \mathrm{~kg}^{-1}$ after manure was additionally applied. Duan et al. [34] also found that combined application of mineral fertilizer and manure could increase maize NAE by $15-86 \%$ at four study sites of China. Our study found that complete substitution of MF with CM results in the significantly lower accumulated $\mathrm{PFP}_{\mathrm{Nac}}, \mathrm{AE}_{\mathrm{Nac}}$ and $\mathrm{RE}_{\mathrm{Nac}}$ at the low fertilizer input level (Level 1, around $56 \mathrm{~kg} \mathrm{~N} \mathrm{ha}^{-1}$ ), but these impacts disappeared with increasing fertilizer rate. The main reasons for differences between our study and the above mentioned studies were: (1) we focused on the accumulated nutrient use efficiency, rather than on the annual nutrient use efficiency and (2) MF was completely substituted by CM in our study rather than a partly substitution as done in the other studies. In our study, $\mathrm{N}$ supply was insufficient for maize growth at low fertilizer rates, available $\mathrm{N}$ was released fast from MF and could be completely used by maize, but available $\mathrm{N}$ from the CM could not be totally released which resulted in lower $\mathrm{PFP}_{\mathrm{Nac}}, \mathrm{AE}_{\mathrm{Nac}}$ and $\mathrm{RE}_{\mathrm{Nac}}$. With increasing fertilizer rate, more available $\mathrm{N}$ was released from $\mathrm{CM}$ to meet the crop demand, the difference between $\mathrm{MF}$ and CM under the same fertilizer input level became smaller, and no significant differences of PFP $\mathrm{Nac}_{\text {, }}$ $A E_{N a c}$ and $R E_{N a c}$ were found between $C M$ and MF. This finding is in agreement with Gai et al. [10], who stated that grain $\mathrm{N}$ concentration in MF treatments was significantly higher than that of manure treatments and that of MF and manure combinations, and consequently results in higher $\mathrm{AE}_{\mathrm{Nac}}$ in $\mathrm{MF}$ than in manure treatments during the 22 years experiment. We also found that $\mathrm{P}$ and $\mathrm{K}$ accumulated use efficiency were similar to $\mathrm{N}$, where maize with MF showed significant higher $\mathrm{PFP}_{\mathrm{Pac}}, \mathrm{PFP}_{\mathrm{Kac}}$, $\mathrm{AE}_{\mathrm{Pac}}$ and $\mathrm{AE}_{\mathrm{Kac}}$ under the lowest fertilizer rate, but with increased fertilizer rates, those differences 
vanished. These results can be explained by the yield gap between MF and CM. However, our study shows that $\mathrm{CM}$ can increase maize $\mathrm{RE}_{\mathrm{Pac}}$, especially at low fertilizer rates which was consistent with Xin et al. [27], who also reported that organic fertilizer can significantly increase $\mathrm{RE}_{\mathrm{Pac}}$ in a 20-year long term experiment. Xin et al. [27] also found that $\mathrm{RE}_{\mathrm{Pac}}$ could reach $81 \%$, which was higher than the values obtained in our study (53\%), mainly because their experiment time was longer. The $\mathrm{RE}_{\mathrm{Pac}}$ over the 20 year experiment was much higher than the results from the short-term experiment [27].

\subsection{Nutrient Balance and Loss}

Soil nutrient balance is essential for enhancing plant growth, while inappropriate fertilizer use might lead to nutrient loss, leaching and pollution of non-agriculture ecosystems. In our study, the use of no fertilizer (CK) could not meet maize nutrient requirements for good growth. Conversely, higher fertilizer application rates (Level 3 and Level 4) significantly raised soil nutrient accumulation, which is beneficial for plant nutrient uptake. Nevertheless, the overuse of fertilizer might result in nutrient loss. $\mathrm{N}$ and $\mathrm{P}$ leaching might pollute the groundwater and increase risks for human health. In our long-term field trial, $\mathrm{N}$ rate about $78 \mathrm{~kg} \mathrm{~N} \mathrm{ha}^{-1}$ was satisfactory for maize production. Extensive use of $\mathrm{N}$ fertilizer at Level $3\left(166.8 \mathrm{~N} \mathrm{ha}^{-1}\right)$ and Level $4\left(222.4 \mathrm{~N} \mathrm{ha}^{-1}\right)$ considerably increased the soil $\mathrm{NO}_{3}-\mathrm{N}$ content in the 0-90 cm soil layer. Ju and Gu [36] stated that soil available $\mathrm{N}$ higher than $90 \mathrm{~kg} \mathrm{ha}^{-1}$ in 0-90 cm soil layer would result in $\mathrm{N}$ leaching in China's farmland. In our experiment, soil $\mathrm{NO}_{3}-\mathrm{N}$ in CM treatments were 93.4 and $252.7 \mathrm{~kg} \mathrm{~N} \mathrm{ha}^{-1}$ respectively for Level 3 and Level 4, which were lower than those of MF treatments (201.3 and $398.5 \mathrm{~kg} \mathrm{~N} \mathrm{ha}^{-1}$, respectively). This means that using MF results in a higher $\mathrm{N}$ leaching risk than using organic fertilizer. However, exclude Level $4 \mathrm{CM}$ treatments $\left(42 \mathrm{mg} \mathrm{kg}^{-1}\right)$, P leaching was not found in our study. The soil available P content was below the threshold for China's farmland $\left(40 \mathrm{mg} \mathrm{kg}^{-1}\right)$ [37]. These results showed that with a reasonable $P$ fertilizer input, the organic form of $\mathrm{P}$ did not increase $\mathrm{P}$ leaching compared with mineral $\mathrm{P}$ fertilizer, but high level of organic fertilizer input (Level 4) might cause P leaching over the long run. Overall, these long-term experiments showed that maize supplied with $6 \mathrm{t} \mathrm{CM} \mathrm{ha}^{-1}$ can meet maize growth demand and would not cause nutrient leaching.

\section{Conclusions}

Fertilizer application rate strongly influenced maize yield and nutrient use efficiencies. The 10-year average maize yields varied from $4.4 \mathrm{tha}^{-1}$ (CK) to $7.6 \mathrm{tha}^{-1}$ (Level 3). However, the yield response to the type of fertilizers (MF and $\mathrm{CM}$ ) across 10 years was similar. Compared with the MF treatments, $\mathrm{CM}$ treatments showed lower maize yields in the first experimental year. As time progressed, $\mathrm{CM}$ treatments displayed slightly better yields than MF treatments. Except for P-RE, at the lowest fertilizer rate (Level 1), maize with MF exhibited better AE, PFP and RE for all the nutrients than maize with CM. However, no clear differences were found between $\mathrm{CM}$ and MF treatments when higher levels of fertilizer were applied. Therefore, low fertilizer rates $\left(6 \mathrm{t} \mathrm{ha}^{-1}\right)$ with $\mathrm{CM}$ are recommended for maize cultivation at the North China Plain. Further improvements of yield and nutrient use efficiencies are possible by studying the nutrient balances.

Supplementary Materials: The following are available online at http://www.mdpi.com/2073-4395/10/9/1329/s1, Table S1: Results of a two-way ANOVA for the analysis of the main effects of fertilizer treatments (T), year (Y), and their interaction $(\mathrm{T} \times \mathrm{Y})$ on maize yield, 1000-kernel weight (TWK), kernel number per ear $(\mathrm{KN})$ and Harvest ear density (ED).

Author Contributions: H.Z. designed the experiment and organized the project. F.F. analyzed the data and wrote the paper. X.N., R.L., X.Z., and Y.Z., collected the data. G.A., L.L., Z.C., and F.Z. revised the manuscript and provided useful comments to improve the manuscript. All authors have read and agreed to the published version of the manuscript.

Funding: This work is supported by the National Natural Science Foundation of China (Grant No. 31800379) and China Postdoctoral Science Foundation (Grant No. 2019M660866).

Acknowledgments: All the authors would like to thank two anonymous reviewers and Professor Hans-Werner Olfs for their helpful comments. 
Conflicts of Interest: The authors declare no conflict of interest.

\section{References}

1. National Bureau of Statistics (NSB). 2019. Available online: http://www.stats.gov.cn/ (accessed on 25 April 2020).

2. Gong, P.; Liang, L.; Zhang, Q. China must reduce fertilizer use too. Nature 2011, 473, 284-285. [CrossRef]

3. Zhen, L.; Zoebisch, M.A.; Chen, G.; Feng, Z. Sustainability of farmers' soil fertility management practices: A case study in the North China Plain. J. Environ. Manag. 2006, 79, 409-419. [CrossRef]

4. Wang, Y.; Yuchun, Z.; Zhang, S.; Wang, Y. What could promote farmers to replace chemical fertilizers with organic fertilizers? J. Clean. Prod. 2018, 199, 882-890. [CrossRef]

5. Bao, W.; Yang, Y.; Fu, T.; Xie, G.-H. Estimation of livestock excrement and its biogas production potential in China. J. Clean. Prod. 2019, 229, 1158-1166. [CrossRef]

6. Cai, A.; Xu, M.; Wang, B.; Zhang, W.; Liang, G.; Hou, E.; Luo, Y. Manure acts as a better fertilizer for increasing crop yields than synthetic fertilizer does by improving soil fertility. Soil Tillage Res. 2019, 189, 168-175. [CrossRef]

7. Xia, L.; Lam, S.K.; Yan, X.; Chen, D. How Does Recycling of Livestock Manure in Agroecosystems Affect Crop Productivity, Reactive Nitrogen Losses, and Soil Carbon Balance? Environ. Sci. Technol. 2017, 51, 7450-7457. [CrossRef]

8. Ghimire, R.; Machado, S.; Bista, P. Soil pH, Soil Organic Matter, and Crop Yields in Winter Wheat-Summer Fallow Systems. Agron. J. 2017, 109, 706-717. [CrossRef]

9. Tang, H.; Xiao, X.; Tang, W.; Li, C.; Wang, K.; Li, W.; Cheng, K.; Pan, X. Long-term effects of NPK fertilizers and organic manures on soil organic carbon and carbon management index under a double-cropping rice system in Southern China. Commun. Soil Sci. Plant Anal. 2018, 49, 1976-1989. [CrossRef]

10. Gai, X.; Liu, H.; Liu, J.; Zhai, L.; Yang, B.; Wu, S.; Ren, T.; Lei, Q.; Wang, H. Long-term benefits of combining chemical fertilizer and manure applications on crop yields and soil carbon and nitrogen stocks in North China Plain. Agric. Water Manag. 2018, 208, 384-392. [CrossRef]

11. Liu, S.; Zhang, H.; Liu, Q.J.; Zong, H.; Yu, X. Effect of long-term application of manure and nitrogen fertilizer on infiltration for a wheat-maize rotation system. Land Degrad. Dev. 2018, 29, 3250-3261. [CrossRef]

12. Gattinger, A.; Muller, A.; Haeni, M.; Skinner, C.; Fliessbach, A.; Buchmann, N.; Mäder, P.; Stolze, M.; Smith, P.; Scialabba, N.E.-H.; et al. Enhanced top soil carbon stocks under organic farming. Proc. Natl. Acad. Sci. USA 2012, 109, 18226-18231. [CrossRef] [PubMed]

13. Hu, C.; Xia, X.; Han, X.; Chen, Y.; Qiao, Y.; Liu, D.; Li, S. Soil organic carbon sequestration as influenced by long-term manuring and fertilization in the rice-wheat cropping system. Carbon Manag. 2018, 9, 619-629. [CrossRef]

14. Su, Y.-Z.; Wang, F.; Suo, D.-R.; Zhang, Z.-H.; Du, M.-W. Long-term effect of fertilizer and manure application on soil-carbon sequestration and soil fertility under the wheat-wheat-maize cropping system in northwest China. Nutr. Cycl. Agroecosyst. 2006, 75, 285-295. [CrossRef]

15. Jokela, W.E. Nitrogen Fertilizer and Dairy Manure Effects on Corn Yield and Soil Nitrate. Soil Sci. Soc. Am. J. 1992, 56, 148-154. [CrossRef]

16. Jiang, H.; Han, X.; Zou, W.; Hao, X.; Zhang, B. Seasonal and long-term changes in soil physical properties and organic carbon fractions as affected by manure application rates in the Mollisol region of Northeast China. Agric. Ecosyst. Environ. 2018, 268, 133-143. [CrossRef]

17. Bao, S. Soil Agrochemical Analysis; China Agricultural Press: Beijing, China, 2000; pp. 25-114. (In Chinese)

18. Wolf, B. A comprehensive system of leaf analyses and its use for diagnosing crop nutrient status. Commun. Soil Sci. Plant Anal. 1982, 13, 1035-1059. [CrossRef]

19. Horowitz, W. Official Methods of Analysis, 11th ed.; The Association of Official Agricultural Chemists: Washington, DC, USA, 1970.

20. Jackson, M. Soil Chemical Analysis; Prentice Hall Inc.: Englewood Cliffs, NJ, USA, 1958; pp. 183-204.

21. Olsen, S.R.; Cole, C.V.; Watanabe, F.S.; Dean, L.A. Estimation of Available Phosphorus in Soils by Extraction with Sodium Bicarbonate; Circular No. 939, 1-19; U.S. Government Printing Office: Washington, DC, USA, 1954.

22. Knudsen, D.; Peterson, G.; Pratt, P. Lithium, sodium, and potassium. In Methods of Soil Analysis: Part 2 Chemical and Microbiological Properties; Monograph Number 9; ASA: Madison, WI, USA, 1983; Volume 9 , pp. 225-246. 
23. Zhao, S.; Qiu, S.; Cao, C.; Zheng, C.; Zhou, W.; He, P. Responses of soil properties, microbial community and crop yields to various rates of nitrogen fertilization in a wheat-maize cropping system in north-central China. Agric. Ecosyst. Environ. 2014, 194, 29-37. [CrossRef]

24. Zhao, B.; Li, X.; Liu, H.; Wang, B.; Zhu, P.; Huang, S.-M.; Bao, D.; Li, Y.; So, H. Results from long-term fertilizer experiments in China: The risk of groundwater pollution by nitrate. NJAS Wagening. J. Life Sci. 2011, 58, 177-183. [CrossRef]

25. Yang, Z.C.; Zhou, L.-D.; Lv, Y.Z.; Li, H. Long-Term Effects of Crop Residual and Inorganic Fertilizers on Yield and Soil Organic Matter for a Winter Wheat-Maize System in North China Plain. Adv. Mater. Res. 2011, 356, 2523-2530. [CrossRef]

26. Zhang, H.; Yu, X.; Jin, Z.; Zheng, W.; Zhai, B.; Li, Z. Improving grain yield and water use efficiency of winter wheat through a combination of manure and chemical nitrogen fertilizer on the Loess plateau, China. J. Soil Sci. Plant Nutr. 2017, 17, 461-474. [CrossRef]

27. Xin, X.; Qin, S.; Zhang, J.; Zhu, A.; Yang, W.; Zhang, X. Yield, phosphorus use efficiency and balance response to substituting long-term chemical fertilizer use with organic manure in a wheat-maize system. Field Crop. Res. 2017, 208, 27-33. [CrossRef]

28. Berry, P.; Sylvester-Bradley, R.; Philipps, L.; Hatch, D.; Cuttle, S.; Rayns, F.; Gosling, P. Is the productivity of organic farms restricted by the supply of available nitrogen? Soil Use Manag. 2002, 18, 248-255. [CrossRef]

29. Zhao, Y.; Wang, P.; Li, J.; Chen, Y.; Ying, X.; Liu, S. The effects of two organic manures on soil properties and crop yields on a temperate calcareous soil under a wheat-maize cropping system. Eur. J. Agron. 2009, 31, 36-42. [CrossRef]

30. Liu, E.; Yan, C.; Mei, X.; He, W.; Bing, S.H.; Ding, L.; Liu, Q.; Liu, S.; Fan, T. Long-term effect of chemical fertilizer, straw, and manure on soil chemical and biological properties in northwest China. Geoderma 2010, 158, 173-180. [CrossRef]

31. Zhang, X.; Fang, Q.; Zhang, T.; Ma, W.; Velthof, G.L.; Hou, Y.; Oenema, O.; Zhang, F. Benefits and trade-offs of replacing synthetic fertilizers by animal manures in crop production in China: A meta-analysis. Glob. Chang. Boil. 2019, 26, 888-900. [CrossRef]

32. Fan, F.; Henriksen, C.B.; Porter, J. Long-term effects of conversion to organic farming on ecosystem services-A model simulation case study and on-farm case study in Denmark. Agroecol. Sustain. Food Syst. 2017, 42, 504-529. [CrossRef]

33. Kato, Y.; Yamagishi, J. Long-term effects of organic manure application on the productivity of winter wheat grown in a crop rotation with maize in Japan. Field Crop. Res. 2011, 120, 387-395. [CrossRef]

34. Duan, Y.; Xu, M.; Gao, S.; Yang, X.; Huang, S.; Liu, H.; Wang, B. Nitrogen use efficiency in a wheat-corn cropping system from 15 years of manure and fertilizer applications. Field Crop. Res. 2014, 157, 47-56. [CrossRef]

35. Vanlauwe, B.; Kihara, J.; Chivenge, P.; Pypers, P.; Coe, R.; Six, J. Agronomic use efficiency of N fertilizer in maize-based systems in sub-Saharan Africa within the context of integrated soil fertility management. Plant Soil 2010, 339, 35-50. [CrossRef]

36. Ju, X.; Gu, B. Indexes of nitrogen management. Acta Pedol. Sin. 2017, 54, 281-296.

37. Zhong, X.; Zhao, X.; Bao, H.; Li, H.; Li, G.; Lin, Q. The evaluation of phosphorus leaching risk of 23 Chinese soils I. Leaching criterion. Acta Ecol. Sin. 2014, 24, 2275-2280.

(C) 2020 by the authors. Licensee MDPI, Basel, Switzerland. This article is an open access article distributed under the terms and conditions of the Creative Commons Attribution (CC BY) license (http://creativecommons.org/licenses/by/4.0/). 